\title{
Chickenpox pneumonia: an association with pregnancy
}

\author{
T F ESMONDE, G HERDMAN, G ANDERSON \\ From Newport Chest Clinic, Newport, Gwent
}

ABSTRACT Three pregnant patients with chickenpox pneumonia are described. A review of report\$\$\$ published since 1965 together with these cases shows that 28 of the 46 women $(61 \%)$ were pregnant ${ }_{D}$ and 21 were in the last trimester. Although the disease is more common and more severe in pregnancy.o the proportion of deaths was no greater than usual. In this retrospective analysis there was nov evidence that treatment with acyclovir conferred benefit but this may have reflected its use only in very ill patients.

\section{Introduction}

In our hospital over two years we have seen three pregnant women with chickenpox pneumonia. This prompted a search of reports published worldwide to find whether chickenpox pneumonia was associated with pregnancy and whether pregnancy affected the outcome.

\section{Case reports}

\section{CASE 1}

A 27 year old woman at 16 weeks' gestation was admitted with a five day history of rash and dyspnoea of two days' duration. She was centrally cyanosed and dyspnoeic at rest, and had a widespread erythematous maculopapular rash with vesicles and harsh breath sounds throughout both lung fields.

Chest radiography showed extensive confluent mottling throughout both lung fields. Arterial blood gas analysis while she was breathing air showed that pH was $7 \cdot 42$, oxygen tension $\left(\mathrm{PaO}_{2}\right) 2 \cdot 3 \mathrm{kPa}$, and carbon dioxide tension $\left(\mathrm{PaCO}_{2}\right) 4 \cdot 3 \mathrm{kPa}$. She was initially treated with $90 \%$ oxygen, which caused the $\mathrm{PaO}_{2}$ to rise to $6.9 \mathrm{kPa}$ while the $\mathrm{PaCO}_{2}$ remained unchanged. As the patient was exhausted, however, ventilation was instituted and nine days later a tracheostomy was performed. Her condition improved subsequently, the tracheostomy was closed, and the patient was discharged 23 days after admission. Blood gas tensions and the chest radiograph had returned to normal. She delivered a healthy female infant by spontaneous vaginal delivery at $\mathbf{4 0}$ weeks' gestation.

Address for reprint requests: Dr G Anderson, Newport Chest Clinic, 129 Stow Hill, Newport, Gwent NP9 4GA.

Accepted 13 July 1989
CASE 2

A 35 year old woman at 30 weeks' gestation was을 admitted with a two day history of rash and dyspnoea of one day's duration, having had contact with a caseo of chickenpox two weeks before. She was centrallye cyanosed and dyspnoeic at rest, with a widespread erythematous macular rash with vesicles.

Arterial blood gas analysis on admission showecp $\mathrm{pH}$ to be 7.43, $\mathrm{PaO}_{2} 6.5 \mathrm{kPa}$, and $\mathrm{PaCO}_{2} 3.3 \mathrm{kPa}$. Th chest radiograph (figure) showed homogeneous shadowing throughout both lung fields. Administra tion of $100 \%$ oxygen did not produce appreciable improvement and assisted ventilation was instituted Intravenous acyclovir was begun at a dose of $5 \mathrm{mg} / \mathrm{k}$ eight hourly. Despite this her condition deteriorated. rapidly and she died 12 hours after admission $\vec{\circ}$ Necropsy showed congested lungs with a liver like

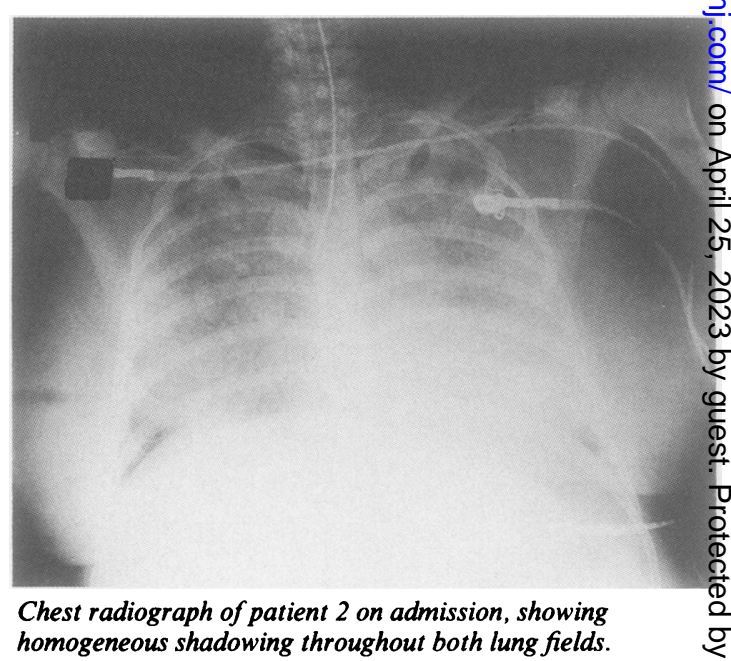


appearance. Microscopy showed bacterial superinfection but no specific changes attributable to chickenpox pneumonia.

\section{CASE 3}

A 25 year old woman at 36 weeks' gestation presented with a two day history of increasing dyspnoea and dry cough. Four days before this she had developed a chickenpox rash. At presentation she was febrile $\left(38^{\circ} \mathrm{C}\right)$, with a typical chickenpox rash, a respiratory rate of $25 / \mathrm{min}$, and tachycardia (130 beats $/ \mathrm{min}$ ). Examination of the chest showed nothing remarkable.

The chest radiograph showed bilateral confluent mottling: Arterial blood gas analysis on admission showed $\mathrm{pH}$ to be 7.38, $\mathrm{PaCO}_{2} 3.5 \mathrm{kPa}$, and $\mathrm{PaCO}_{2} 5.5$ $\mathrm{kPa}$. The patient was given $60 \%$ oxygen and intravenous acyclovir $10 \mathrm{mg} / \mathrm{kg}$ eight hourly. Her condition deteriorated over the next six hours and an emergency caesarian section was performed. Assisted ventilation was continued postoperatively. A healthy baby girl was delivered, who developed chickenpox six days after birth. The mother was ventilated for a total of five days and had acyclovir for seven days. Recovery was complicated by a deep venous thrombosis in the right calf. Mother and baby were discharged three weeks later. Arterial blood gas tensions and the chest radiograph had returned to normal.

\section{Review of previous reports}

A review of the reports published since $1965^{1-34}$ combined with our three cases yields a description of 99 adults with chickenpox pneumonia (table 1).

Of the 46 women (in nine others the sex was not stated), 28 were pregnant, indicating a clear association with pregnancy. The disease occurred in the third trimester in 21 and in the second in three; the duration of pregnancy was not stated in four. As judged by the number requiring assisted ventilation, chickenpox pneumonia appeared to be a more serious illness in pregnancy, but mortality (11\%) was similar to that in non-pregnant patients. Treatment with antiviral agents did not appear to confer benefit; five of 44 patients $(11 \%)$ receiving acyclovir and none of six patients receiving other antiviral agents died, compared with five of $49(10 \%)$ patients who received no antiviral drug $\left(\chi^{2}=0.178, p>0.5\right.$ for summation of results). The benefit from acyclovir could be obscured if patients were given the drug only if they were more ill than those who were not. When adult mortality in the era before the introduction of acyclovir was compared with that in the period after its introduction no significant difference was found (table 2).

When the mother survived infant mortality was low and only one infant died. Six infants were delivered during the illness and 15 after it. Only two infants born alive developed chickenpox.

\section{Discussion}

The varicella-zoster virus is a highly contagious DNA virus. Five per cent of women in the child bearing age lack specific IgG and are therefore susceptible. Varicella has been thought to be relatively infrequent in pregnancy, with an incidence of 0.7 per 1000 pregnancies. ${ }^{35}$ In the United States the mean incidence for women of $15-45$ years of age is $2 \cdot 2 / 1000 /$ year.

Carstairs and Emond ${ }^{36}$ in 1963 reported 120 patients from published reports with acute chickenpox pneumonia, and Knyvett (1965) ${ }^{37}$ described a personal series of 35 cases. In these earlier descriptions clinical data were scanty and Knyvett did not record the age or sex incidence, or whether any of the patients were pregnant. For these reasons we have confined our analysis to patients described since 1965 .

Only four of the cases that occurred during pregnancy occurred outside the last trimester. This may be explained by the progressive changes in the immune system that occur in pregnancy, ${ }^{38}$ the immune system

Table 2 Numbers of patients surviving before and after the introduction of acyclovir

\begin{tabular}{lll}
\hline & Survived & Died \\
\hline Before acyclovir & 29 & 1 \\
Acyclovir era & 60 & 9 \\
\hline
\end{tabular}

$\chi^{2}=1 \cdot 23, \mathrm{p}>0.02$.

Table 1 Adult chickenpox pneumonia: a review of previously published cases combined with the present three (number (\%))

\begin{tabular}{|c|c|c|c|c|c|c|}
\hline & Sex & Ventilated & Died & Acyclovir used & $\begin{array}{l}\text { Other } \\
\text { antiviral agents } \ddagger\end{array}$ & Fetus died \\
\hline Non-pregnant $(n=71)$ & $\begin{array}{l}\text { M } 44 \\
F \quad 18 \\
?=9 \dagger\end{array}$ & $\begin{array}{l}13(18) \\
(? 18+)\end{array}$ & $7(10)$ & 28 (39) & $2(3)$ & \\
\hline Pregnant $(n=28)^{*}$ & & $13(46)$ & $3(11)$ & $16(57)$ & $4(14)$ & $3(11)$ \\
\hline
\end{tabular}

* Twenty one in last trimester and four unknown.

+ Not stated.

¥Cytosine arabinoside, idoxuridine, gammaglobulin, adenine arabinoside. 
being required to mount a normal immune response to exogenous antigen while not mounting a response against the foreign antigen of the fetal trophoblast. This task is accomplished by several changes in the immune system: the thymus becomes progressively involuted owing to increased concentrations of oestradiol and corticosteroids, the number of monocytes is increased (though there are conflicting reports about the number of $T$ and $B$ cells), and there is an increase in leucocyte phagocytic and bactericidal responses. Other abnormalities, such as antibody and allergen responses, are less clearly defined. These immunological disturbances of pregnancy may be mediated by pregnancy associated globulins. Pregnancy is associated with an increased incidence of influenza, cytomegalovirus and Haemophilus influenza infections, and tuberculosis. ${ }^{39-41}$ Early delivery of the infant during the illness is unnecessary to save the mother's life. This is at variance with the experience in Lassa fever. ${ }^{42}$

Only two infants developed chickenpox after delivery. In both cases delivery occurred within four days of the mother's developing chickenpox, allowing no time for her protective IgG to cross the placenta to protect the infant.

Antiviral treatment, in particular the introduction of acyclovir in 1979, does not apper to have altered the outcome and its role in treatment is unproved.

Diffuse pulmonary calcification may occur three to 10 years after chickenpox pneumonia, and this was present in three of 21 patients who underwent prolonged follow up. In the present review of 99 patients none had pulmonary calcification, but this probably reflects the brief duration of follow up.

Patient 3 was under the care of Dr J Davies and we are grateful for his permission to describe the case.

\section{References}

1 Leen CL, Mandal BK, Ellis ME, Brettle RP. Acyclovir and pregnancy [letter]. $\mathrm{Br} \mathrm{Med} J$ 1987;294:308.

2 Weber DM, Pellecchia JA. Varicella pneumonia: a study of prevalence in adult men. JAMA 1965;192:228-9.

3 Pillans P. Chicken-pox pneumonia. S Afr Med J 1983;63:861-2.

4 Triebwasser JH, Harris RE, Bryant RE, Rhoades ER. Varicella pneumonia in adults: report of seven cases and review of the literature. Medicine (Baltimore) 1967;46:409-23.

5 Harris RE, Rhoades ER. Varicella pneumonia complicating pregnancy: report of a case and review of the literature. Obstet Gynecol 1965;25:734-40.

6 Hankins GD, Gillstrap III LC, Patterson AR. Acyclovir treatment of varicella pneumonia in pregnancy [letter]. Crit Care Med 1987;15:336-7.
7 Williams MT, Marsland DW. Varicella pneumonia at parturition: a non-fatal case. J Fam Pract 1976;3:0 153-4.

8 Winkelmann RK, DeRemee RA, Ritts RE. Treatment of $\overline{\bar{c}}$ varicella-zoster pneumonia with transfer factor. Cutis $\vec{\Phi}$ 1984;34:278-81.

9 Scully RE, Galdabini JJ, McNeely BU, eds. Case records of the Massachusetts General Hospital: weekly clinico-pathological exercises: case 9: 1976. $N$ Engl J Med? 1976;294:485-93.

10 MacFarlane JT, Smith FD, Finch RG. Vidarabine in fulminating chickenpox pneumonia. Thorax 1982;37:226-7.

11 Boyd K, Walker E. Use of acyclovir to treat chickenpox $\vec{A}$ in pregnancy. $\mathrm{Br}$ Med $J$ 1988;296:393-4.

12 Lowthian JT, Gillard LJ. Varicella pneumonia in the gravid patient. J L A State Med Soc 1980;132:69-70. $\vec{N}$

13 Duong CM, Munns RE. Varicella pneumonia duringo pregnancy. J Fam Pract 1979;8:277-80.

14 Chitkara R, Gordon RE, Khan FA. Acyclovir in the $\overrightarrow{-}$ treatment of primary varicella pneumonia in nonimmunocompromised adults [letter]. NY State J Medo 1987;87:237-8.

15 Munnich D. Nagy kiterjedesu ketoldali tudogyulladassal jaro felnottkori varicella progressiva esetunk sikeres intravenas Zovirax/acyclovir/kezelese. Orvosi Hetilap. 1985;126:1663-5.

16 Kuster W, Hofner W, Wicke L, Kuhbock J. Varicellen-O pneumonie bei Morbus Hodgkin. Radiologe 1987; 18:398-400.

17 Raidt H, Gottschalk D, Krummenerl T, et al. Acyclovir̊ bei schwerer Varizellapneumonie und bei Herpes@ ophthalmicus. Praxis 1983;72:1179-82.

18 Tatti V. La pneumonie à varicelle chez l'adulte. Rev Med? Suisse Romande 1975;95:263-7.

19 Landsberger EJ, Hager WD, Grossman III JH. Success ful management of varicella pneumonia complicating:pregnancy: a report of 3 cases. $J$ Reprod Med 1986;31:311-4.

20 Ellis ME, Neal KR, Webb AK. Is smoking a risk factor: for pneumonia in adults with chickenpox? $\mathrm{Br} \mathrm{Med}$ 1987;294:1002.

21 van der Meer JW, Thompson J, Tan WD, Versteeg J.ळ̊ Treatment of chickenpox pneumonia with acyclovir? [letter]. Lancet 1980;ii:473-4.

22 Teare EL, Cohen JA. Treatment of chickenpox pneumonia with adenine arabinoside [letter]. Lanceto 1979;i:873.

23 Aizawa H, Ohsaki Y, Sakai E, Ikeda Y, Kuwajima T, N Onodera S. Two cases of primary varicella pneumonia [Japanese]. Nippon Kyobu Shikkan Gakkai Zasshio 1986;24:195-9.

24 Selleger C. Pneumonie varicelleuse mortelle chez l'adulte:0 rapport de deux cas et revue de la litterature. $R e v F_{t}$ Mal Respir 1979;7:9-18.

25 Bryer A, Potgeiter PD, Moodie J. Acyclovir and varicellaç pneumonia [letter]. S Afr Med J 1984;66:515.

26 Eder SE, Apuzzio JJ, Weiss G. Varicella pneumoniaduring pregnancy: treatment of two cases with acyclovir. Am J Perinatol 1988;5:16-8.

27 Myint SS, Lee SK. Chickenpox pneumonia: a case report Singapore Med J 1986;27:80-3. 
28 Wolters J, Maesen F, Lamers J. Varicellapneumonie. Ned Tijdschr Geneeskd 1979;123:1777-82.

29 Davidson RN, Lynn W, Savage P, Wansbrough-Jones MH. Chickenpox pneumonia: experience with antiviral treatment. Thorax 1988;43:627-30.

30 Hammershoy O. Primaer varicelpneumoni. Ugeskr Laeger 1979;141:1855.

31 Harper JR, Marshall RD, Parkinson MS. Intermittent positive-pressure ventilation in chickenpox pneumonitis. $\mathrm{Br}$ Med J 1969;iii:637-8.

32 Glaser JB, Loftus J, Ferragamo V, Mootabar H, Castellano $M$. Varicella-zoster infection in pregnancy. [letter]. N Engl J Med 1986;315:1416.

33 Paryani SG, Arvin AM. Intrauterine infection with varicella-zoster virus after maternal varicella. $N$ Engl J Med 1986;314:1542-6.

34 Schlossberg D, Littman M. Varicella pneumonia. Arch Intern Med 1988;148:1630-2.

35 Enders G. Varicella-zoster virus infection in pregnancy. Prog Med Virol 1984;29:166-96.

36 Carstairs LS, Emond RTD. Chickenpox virus pneumonia. Proc $R$ Soc Med 1963;56:267-70.

37 Knyvett AF. The pulmonary lesions of chickenpox. $Q J$ Med 1966;166:313-23.

38 Head JR, Billingham RE. Immunobiological aspects of the maternal-fetoplacental relationship. In: Lachmann PJ, Peters DK, eds. Clinical aspects of immunology. 4th ed. Vol 1. Oxford: Blackwell 1982:243-82.

39 Eickoff TC, Shermon IL, Serfling RE. Observations on excess mortality associated with epidemic influenza. JAMA 1969;176:776-82.

40 Kumar ML, Prokay SL. Experimental primary cytomegalovirus infection in pregnancy: timing and foetal outcome. Am J Obstet Gynecol 1983;145:56-60.

41 Sanberg T, Dahlbert T. Meningitis and septicaemia due to Haemophilus influenzae type B in pregnancy. $\mathrm{Br} \mathrm{Med}$ J 1981;282:584-6.

42 Price ME, Fisher-Hoch SP, Craven RB, et al. A prospective study of maternal and fetal outcome in acute Lassa Fever infection during pregnancy. $\mathrm{Br} \mathrm{Med} J$ 1988; 297:584-6. 